536.33

沃[110]ふく射に関与し，熱発生をともなう気体を含 む球形容器内のふく射熱伝達 [E.M. Sparrow, C.M. Usiskin, \& H.A. Hubbard, Trans. ASME, Series C, 1961-5, Vol. 83, No. 2, p. 199 206, 図 8, 表 1] 中空の球，または二重円筒内にふく射吸収および放 射を行なう非均一温度で, かつ熱発生をともなう気体 がはいっている場合についてのふく射に対する解析が 行なわれててい，ただし対流と伝導は考慮されていな い. 気体は灭色で，単位体積当りの熱発生量は一定と し，境界の壁は黒色で均一温度と仮定されている。気 体の微小体積に対してエネルギ保存則を用い積分方程 式を導き，それの数值解を求め気体のふく射能 (温度) 分布を, $K R_{2}=0.1,0.5,1.0,2.0$ の各場合に対して $R_{1} / R_{2}=0,0.05,0.5,0.75,0.95$ ，の五つの場合につ いて示してある $\left(R_{1}, R_{2}\right.$ : 内筒および外筒半徍， $K$ : 氛体のふく射吸收係数). この結果を使用して内筒お よび外筒への熱伝達量が計算され，上記の場合では外 筒への熱伝達量が内筒のものより大きいことが示され ている. 最後に $1 / K$ が代表長さに比較して十分小さ いという仮定のもとでの近似解析（天体物理で使用さ れている）を行ない，その結果と上記の結果とを比較 している. $K R_{2}=2$ の場合には両者の差は最大約 $20 \%$ である。

[黒崎 晏夫]

\section{$536.33: 535.231$}

※[111]簡単な配列の灰色表面間のふく射についての 解析; 結果および説明 [E.M. Sparrow, J.L. Gregg, J.V. Szel, \& P. Manos, Trans. ASME, Series C, 1961-5, Vol. 83, No. 2, p. 207〜214, 図 10, 表 2]

幅は無限で長さは有限長さ $L$ の 2 枚の平板が $\theta$ の 刍度で交わっている場合，およびそれと同じ平板が間 隔 $h$ で平行に置かれている場合のふく射についての解 析を行なっている．仮定としては両面は同じ均一温度 にあり，また両表面のふく射物性值は同じであり，ま た平板間の気体はふく射および吸収を行なわないもの としている．解析の目的としては，第一にふく射によ る局所熱流束の分布が幾何形状とふく射物性值により どのように影響を受けるかを示すこと，拉よび第二に 実際面に役立つように局所熱流束の分布を使って物理 的説明が行なわれている。また全熱流束も求められて いる. 前者の場合に対して $\theta=135^{\circ}, 90^{\circ}, 60^{\circ}$, およひ $45^{\circ}$ で $\epsilon$ (ふく射率 $)=0.01,0.5$ および 0.9 の各場合 に対して熱流束分布が求められている.これらはフイ ンのふく射等に店用可能である．後者の場合に対して は $h / L=1.0,0.5,0.1$ および 0.05 で $\epsilon$ は前者同様 の各場合に対して同じ計算が行なわれている，板の端 の部分の熱損失について説明がなされている.

\section{[黒㱦 晏夫]}

\subsection{3 .1}

[112]表面核沸騰の機構について [S.G. Bankoff， Chem. Engng. Progr. Symposium Series, 1961, Vol. 57, No. 32, p. 156 172, 図 15, 表 2] 本論 文は強制対流をしている過冷液体に主体をおき，核沸 腾の伝熱機構に対する新理念を導き, Gunther(1)の実 験結果を利用してその妥当性を検討したものである. 著者はます固体壁より核心流への熱伝達を, (1) 伝熱面 加ら二相境界層の内側 ，(2) 二相境界層の内側名ら外
側一，(3) 二相境界層の外側より単相核心流へ，の三つ の段階に分けている.（1）の段階における熱流は，(a) 気ほうによって周期的におおわれる部分の熱流と，(b) 常に液体に接する部分の熱流，との和と考え，(a) の熱 負荷および気ほう間に誘起される液体の速度变動の平 均振幅を表わす式を誘導している。上述の二つの熱流 のうちいずれが優勢であるかについては現在のところ 明らかでない.(3)の段階における熱伝達は主として乱 流昖散によって生じる. 主流速ちよび気隹うう運動のい すれもこの班散に寄与するが，低熱負荷では前者が， 高熱負荷では後者が主要になってくる。この場合の熱 負荷の式が誘導され，Guntherの実験值とよく一致す ることが示されている。しかしの式は気ほう径，平 均表命，気ほうによっておおわれる伝熱面の割合など の気はうに関する因子を含んで抢り，実用のためには さらに研究が必要である，ついで単相乱流核心におけ る温度分布を Gunther の実験データに対して計算し, またレイノルズの類似則が壁までのすべての熱通路に 対して成立すると仮定して，二相境界層との界面にお ける液体温度をあらわす式を求め，バーンアウトに近 づくと，その温度が飽和温度に急激に近つくことを見 出している.このことは上述の（3）の伝熱過程がバー ンアウトの近傍で重要になることを意味するものと思 われる.さらに(1)と（3）の段階の熱伝達に対して熱負 荷に影響を及注す各因子の効果が計算され，Gunther の実験值とよく一䏽することが示されている．しかし (2)の伝熱過程については, 潜熱輸送の相対的重要性に 関する知識が必要であり, 今後の研究が期待される。

(1) F.C. Gunther, Prog. Rep., No. 4-75, (1950). JPL, Cal. Inst. Technol.

[西川兼康]

\section{$532.13 .082 .2: 546.212$}

[113] $700^{\circ} \mathrm{C}$ および 800 at までの水と水蒸気の粘 性測定 [F. Mayinger, International Journal of Heat and Mass Transfer, 1962-9, Vol. 5, No. 9, p. 807〜824, 図 8, 表 2]細管法によって高温高圧 での水と水蒸気の粘性を測定するに当って，管の出入 口端での圧力差 $\Delta p$, 内径 $d$, 長さ $L$, 流体の密度 $\rho$, 平均流速 $u$, レイノルズ数 $R_{e}$ を用い, $\Delta p / \frac{1}{2} \rho u^{2}=$ $\left(64 L / R_{e} d\right)+C$ とおき, 大口端の補正量 $C$ (Couette の定数）を求めるために，空気を $100<R_{e}<400$ の垶 国で流し， $C=2.3$ を得た。管徍は $\mu$ に四乘できいて くるので䢃密測定のために，室温室生付近では粘性が 既知である $99.99 \%$ の空素を流し， $10^{-5} \mathrm{~mm}$ まで敗 定，熱膨張は後に補正した。細管は 白金製で出入口間の压力差は特殊マ ノメータで $0.05 \mathrm{mmHg}$ まで測定し た。使用する水は 2 回蒸留した後, 数時間沸点で保持してガスを抜い た. 測定は 1 時間以上定常維持の後 に開始し，その範围は第 2 表のとお りである. 測定された 管長，凝結水量，差圧，水銀桂上の 水柱, 温度, 絶対圧, 蒸気表数值, 水中残留ガス，凝結器温度の変動などによるものを含 めて $\pm 1.5 \%$ 以内と推定される. [寺田 耕] 